\title{
ANALYSIS OF THE AVAILABILITY OF WATER RESOURCES AND CONSERVATION LESTI SUB-BASIN DISTRICT OF MALANG
}

\author{
Abdul Somat Bukoria dan Rachmat Boedisantoso ${ }^{b}$
}

\begin{abstract}
Lesti sub basins is one of the upstream part of the Brantas river basin located in the district of Malang. Conditions Lesti sub-basins have been damaged thereby potentially Experiencing a water deficit. The deficit of water in the dry season in 2017 Amounted to 2,141,057 $\mathrm{m}^{3}$ and 2023 Amounted to 3,881,593 $\mathrm{m}^{3}$. To overcome the deficit of water carried out an analysis of the conservation of water resources. This analysis is carried out, among others, plant conservation and mechanical. Conservation of vegetation done by planting of agarwood trees. While mechanically performed with rainwater harvesting with the roof and the building of the embung. The results of the analysis of the required land area until the year 2023 with the planting of agarwood trees covering an area of $18.27 \mathrm{~km}^{2}$. Rainwater harvesting using roofs as much as 2 water storage tanks with a capacity each of $32 \mathrm{~m}^{3}$. Embung needs as much as 3 each reservoir capacity of $800,000 \mathrm{~m}^{3}$. Embung investment costs Rp. 207,205,545,000 Done in 2017 until 2018.
\end{abstract}

Keywords: district of malang, water requirements; availability of water; conservation; Lesti sub basin.

Abstrak: Sub DAS Lesti merupakan salah satu bagian hulu DAS Brantas yang terletak di wilayah Kabupaten Malang. Kondisi sub DAS Lesti telah mengalami kerusakan sehingga berpotensi mengalami defisit air. Defisit air pada musim kemarau pada tahun 2017 sebesar $2.141 .057 \mathrm{~m}^{3}$ dan tahun 2023 sebesar $3.881 .593 \mathrm{~m}^{3}$. Untuk menangani defisit tersebut dilakukan analisis konservasi sumber daya air. Analisis tersebut meliputi konservasi secara vegetasi dan mekanis. Konservasi vegetasi dilakukan dengan penanaman pohon gaharu sedangkan secara mekanis dilakukan dengan pemanen air hujan dengan media atap rumah dan pembuatan embung. Dari hasil analisis diketahui luas lahan yang dibutuhkan sampai tahun 2023 dengan penanaman pohon gaharu seluas 18,27 km². Kebutuhan pemanen air hujan sebanyak 2 bak penampung kapasitas masing-masing $32 \mathrm{~m}^{3}$. Kebutuhan embung sebanyak 3 embung kapasitas masing-masing $800.000 \mathrm{~m}^{3}$. Biaya investasi embung Rp. 207.205.545.000,- dikerjakan pada tahun 2017 sampai 2018.

Kata Kunci: kabupaten malang, kebutuhan air, ketersediaan air, konservasi, sub DAS Lesti

\section{PENDAHULUAN}

Sub DAS Lesti merupakan salah satu bagian hulu DAS Brantas yang terletak di wilayah Kabupaten Malang. Kondisi sub DAS Lesti telah mengalami kerusakan sehingga berpotensi mengalami defisit air. Defisit air pada musim kemarau pada tahun 2017 sebesar $2.141 .057 \mathrm{~m}^{3}$ dan tahun 2023 sebesar $3.881 .593 \mathrm{~m}^{3}$. Untuk mengatasi defisit tersebut dilakukan upaya konservasi baik secara vegetasi dan mekanis. Upaya konservasi dengan metode vegetasi dengan penanaman pohon gaharu. Secara mekanis dengan pemanen air hujan (PAH) media atap rumah dan pembangunan embung. Tujuan dari tesis ini adalah mengetahui defisit air yang terjadi pada tahun proyeksi, kebutuhan luasan lahan vegetasi, kebutuhan bak penampung PAH dan embung untuk mengatasi defisit, serta dari aspek finansial pembangunan embung layak untuk dikerjakan atau tidak.

\section{KEPENTINGAN RISET}

Kepentingan riset/tesis ini adalah menganalisis ketersediaan air yang ada di sub DAS Lesti pada saat ini sampai tahun 2023. Menganalisis konservasi sumber daya

${ }^{\text {a}}$ Personnel at the BBWS Brantas, and a student in the Department of Civil Engineering, Sepuluh Nopember Institute of Technology (ITS), ITS Campus, Sukolilo, Surabaya 60111, Indonesia. Email: abdulsomatbukori@gmail.com

${ }^{b}$ Lecturer in the Department of Environment Engineering, Sepuluh Nopember Institute of Technology (ITS), ITS Campus, Sukolilo, Surabaya 60111, Indonesia. Email:totok_m@ee.its.ac.id

Note. The manuscript for this paper was submitted for review and possible publication on January 01, 2017. This paper is part of the ITS Journal of Civil Engineering, Vol. 32, No. 1, May 2017. (C ITS Journal of Civil Engineering, ISSN 2579-9029/2017. air untuk meminimalisir defisit air pada musim kemarau dan menjaga keberlangsungan kuantitas sumber daya air sampai tahun 2023. Menganalisis kelayakan secara finansial dalam upaya konservasi sumber daya air. Diharapkan hasil penelitian ini bisa dijadikan sebagai konsep terpadu dalam pengelolaan sumber daya air, khususnya di sub DAS Lesti terutama pada masa kekeringan. Dengan pengelolaan sumber daya air yang baik, diperoleh ketersediaan air yang memenuhi secara berkelanjutan. Pengelolaan sumber daya air yang baik juga dapat meminimalisir krisis air bersih dalam penyediaan air untuk sektor-sektor penting lainnya yang selalu terjadi setiap tahun.

\section{METODOLOGI}

Tesis ini merupakan suatu penelitian kuantitatif, berupa analisis terhadap kondisi saat ini dan ketersediaan air di sub DAS Lesti di wilayah Kabupaten Malang. Langkah-langkah yang dilakukan antara lain, pengumpulan data-data primer dan sekunder (data ketersediaan air dan kebutuhan air), melakukan analisis teknis, analisis lingkungan dan finansial. Data-data primer dan sekunder yang telah didapat, langkah berikutnya melakukan analisis teknis. Analisis teknis antara lain menghitung: curah hujan rerata daerah (Metode Poligon Thieesen), analisis suhu, evapotranspirasi potensial (ETo) (Metode Thornthwaite), analisis debit (Metode FJ. Mock).

Perhitungan debit efektif dan debit andalan sebagai salah satu dasar perhitungan kebutuhan air. Kebutuhan air non irigasi berdasarkan proyeksi penduduk, kebutuhan air domestik. Setelah ketersediaan air diperoleh dari perhitungan FJ. Mock, maka sebelum melanjutkan perhitungan perlu dikalibrasi dengan debit Kali Lesti 
kondisi nyata (AWLR). Selisih antara ketersediaan air dengan kebutuhanan air menggambarkan kondisi ketersediaan air pada wilayah studi. Jika selisih antara keduanya bernilai positif, maka kondisi ketersediaan air surplus, dan sebaliknya. Dari dasar ini dilakukan analisis konservasi sumber daya air (upaya konservasi vegetatif dan mekanik) yang bertujuan menjaga dan melestarikan keberadaan air pada suatu DAS. Analisis konservasi sumber daya air meliputi analisis metode vegetasi dan analisis metode mekanis. Analisis metode vegetasi didasarkan pada luas lahan vegetasi dan potensi sebaran vegetasi. Potensi sebaran vegetasi menggunakan tanaman gaharu, bambu dan tanaman porang. Analisis metode mekanik menggunakan pemanen air hujan melalui atap, dan pembangunan embung. Setelah analisa teknis selesai hingga muncul volume tampungan embung, langkah berikutnya adalah analisa aspek finansial. Analisis finansial ini menggunakan metode NVP dan BCR. Tujuan analisa ini, apakah upaya konservasi dengan pembuatan embung layak untuk dilakukan.

\section{ANALISIS}

Analisis yang dilakukan antara lain: Analisis Teknis, Konservasi Sumber Daya Air dan Finansial. Analisis teknis yang ditinjau adalah kebutuhan air dan ketersediaan air. Kebutuhan air yang akan di analisa antara lain kebutuhan air domestik, perkantoran, fasilitas kesehatan, fasilitas pendidikan, tempat ibadah, dan peternakan. Untuk mengetahui besar kebutuhan air, maka terlebih dahulu harus diketahui jumlah penduduk yang ada pada wilayah yang akan di analisa dan juga besar pertumbuhan penduduk pada wilayah tersebut sebagai acuan proyeksi jumlah penduduk untuk tahun yang akan datang. Dari data tersebut kemudian dihitung tingkat pertumbuhan tiap tahun. Analisi ketersediaan air di sub DAS Lesti diperoleh dari perhitungan FJ. Mock dan dikalibrasi dengan debit Kali Lesti kondisi nyata. Debit nyata didapat dari data AWLR dalam kurun waktu tertentu. Analisis konservasi sumberdaya air diperlukan dalam rangka upaya untuk menjaga dan melestarikan keberadaan air pada suatu daerah aliran sungai.

Usaha konservasi tersebut dapat menggunakan 2 metode yang meliputi metode vegetasi dan pemanen air hujan baik dengan media atap rumah maupun embung. Analisis finansial yang ditinjau adalah biaya modal/investasi; perhitungan manfaat yang identik dengan kerugian kekeringan yang timbul bila tidak dilakukan sesuatu; perhitungan kerugian dan keuntungan. Parameter yang digunakan yaitu metode IRR, NPV dan BCR. Tujuan analisa ini, adalah untuk menentukan luasan lahan vegetasi, jumlah kebutuhan PAH dan embung serta menilai pembangunan embung apakah layak untuk dilakukan atau tidak. Dalam rangka upaya untuk menjaga dan melestarikan keberadaan air pada suatu daerah aliran sungai.

Usaha konservasi tersebut dapat menggunakan 2 metode yang meliputi metode vegetasi dan pemanen air hujan baik dengan media atap rumah maupun embung. Analisis finansial yang ditinjau adalah biaya modal/investasi; perhitungan manfaat yang identik dengan kerugian kekeringan yang timbul bila tidak dilakukan sesuatu; perhitungan kerugian dan keuntungan. Parameter yang digunakan yaitu metode IRR, NPV dan BCR. Tujuan analisa ini, adalah untuk menentukan luasan lahan vegetasi, jumlah kebutuhan PAH dan embung serta menilai pembangunan embung apakah layak untuk dilakukan atau tidak.

\section{PEMBAHASAN}

\section{Analisis Kebutuhan Air dan Ketersediaan Air}

Kebutuhan air dihitung untuk kondisi saat ini (2016) dan tahun prediksi sampai 2023. Kebutuhan air domestik dan non domestik dihitung berdasarkan jumlah penduduk dan konsumsi pemakaian air per jiwa per hari. Pada tesis ini konsumsi pemakaian air mengacu pada laporan tahun 2015 PDAM Kabupaten Malang. Sebelum menghitung kebutuhan air domestik terlebih dahulu dilakukan proyeksi penduduk hingga tahun 2023. Proyeksi penduduk adalah memprediksi jumlah penduduk pada tahun tertentu dengan konversi rata-rata tahunan pertumbuhan penduduk. Dalam melakukan proyeksi penduduk digunakan beberapa metode antara lain: metode aritmatik, geometrik dan last square untuk mendapatkan nilai $r$ (nilai korelasi) yang mendekati 1 (satu).

Setelah dilakukan proyeksi jumlah penduduk, maka langkah selanjutnya adalah menghitung kebutuhan air domestik. Jumlah air yang dibutuhkan perkapita per hari ditetapkan berdasarkan laporan pemakaian rata-rata PDAM Kabupaten Malang tahun 2015. Jumlah pemakaian rata-rata tiap orang (untuk pelanggan rumah tangga) tiap hari adalah 94,87 ltr/orang/hari (PDAM Kab. Malang, 2015). Untuk kebocoran/air tanpa rekening/non revenue water (NRW) pada tahun 2014 tercatat sebesar 29,68\% (PDAM Kab.Malang, 2014). Kebutuhan air non domestik adalah kebutuhan air bersih di luar kebutuhan rumah tangga, antara lain: kebutuhan air perkantoran, fasilitas kesehatan, penginapan, pendidikan, tempat peribadatan, peternakan, dan industri. Kebutuhan total air domestik dan non domestik sesuai proyeksi dapat dilihat pada Tabel 1 dan 2 .

\section{Analisis Keseimbangan Air/Potensi Air Permukaan}

Keseimbangan air di Sub DAS Lesti diperoleh dengan membandingkan kebutuhan dan ketersediaan air untuk kondisi sekarang (2016) dan tahun-tahun yang diproyeksikan. Ketersediaan air didasarkan pada debit andalan $90 \%$ (non irigasi). Kebutuhan air non irigasi (domestik dan non domestik) adalah konstan sepanjang tahun (Bambang Triadmojo, 2008). Selisih antara ketersediaan dengan kebutuhan air menggambarkan kondisi ketersediaan air pada wilayah studi, jika selisih keduanya bernilai positif, maka kondisi ketersediaan air surplus dan sebaliknya merupakan kondisi keseimbangan air yang ditunjukkan Tabel 3. Dengan hasil rekapitulasi lama waktu kebutuhan air tiap tahun ditunjukkan dalam Tabel 4. 
Tabel 1. Kebutuhan Air Domestik

\begin{tabular}{|c|c|r|r|r|r|}
\hline No. & Tahun & $\begin{array}{c}\text { Jumlah } \\
\text { Kebutuhan } \\
\text { (lt/dt) }\end{array}$ & $\begin{array}{c}\text { Kebocoran } \\
\text { Air }(\%)\end{array}$ & $\begin{array}{c}\text { Total } \\
\text { Kebutuhan } \\
\text { Air (lt/dt) }\end{array}$ & $\begin{array}{c}\text { Total } \\
\text { Kebutuhan } \\
\text { Air (m3/dt) }\end{array}$ \\
\hline 1 & 2016 & $1.009,71$ & 29,68 & $1.309,39$ & 1,31 \\
\hline 2 & 2017 & $1.014,34$ & 29,68 & $1.315,39$ & 1,32 \\
\hline 3 & 2018 & $1.018,99$ & 29,68 & $1.321,42$ & 1,32 \\
\hline 4 & 2020 & $1.028,37$ & 29,68 & $1.333,59$ & 1,33 \\
\hline 5 & 2023 & $1.042,64$ & 29,68 & $1.352,09$ & 1,35 \\
\hline
\end{tabular}

Tabel 2. Total Kebutuhan Air Non Domestik

\begin{tabular}{|c|c|c|c|c|c|c|c|c|c|}
\hline No & Tahun & $\begin{array}{c}\text { Jumlah } \\
\text { Keb.Air } \\
\text { Perkantorn } \\
\text { (lt/dt) }\end{array}$ & $\begin{array}{c}\text { Jumlah } \\
\text { Keb.Air Fas. } \\
\text { Kesehatan } \\
\text { (lt/dt) }\end{array}$ & $\begin{array}{c}\text { Jumlah } \\
\text { Keb.Air } \\
\text { Fas. } \\
\text { Pendidikan } \\
\text { (lt/dt) }\end{array}$ & $\begin{array}{c}\text { Jumlah } \\
\text { Keb.Air } \\
\text { Tempat } \\
\text { Ibadah } \\
\text { (lt/dt) }\end{array}$ & $\begin{array}{c}\text { Jumlah } \\
\text { Keb.Air } \\
\text { Peternakan } \\
\text { (lt/dt) }\end{array}$ & $\begin{array}{c}\text { Keboco } \\
\text { ran Air } \\
(\%)\end{array}$ & $\mid \begin{array}{c}\text { Total } \\
\text { Kebutuhan } \\
+ \\
\text { Kebocoran } \\
\text { (lt/dt) }\end{array}$ & $\begin{array}{c}\text { Total } \\
\text { Kebutuhan } \\
+ \\
\text { Kebocoran } \\
\text { (m3/dt) }\end{array}$ \\
\hline 1 & 2016 & 1,14 & 4,05 & 30,68 & 219,44 & 164,96 & 29,68 & 545,01 & 0,55 \\
\hline 2 & 2017 & 1,18 & 4,07 & 30,82 & 220,45 & 197,61 & 29,68 & 588,91 & 0,59 \\
\hline 3 & 2018 & 1,21 & 4,09 & 30,97 & 221,46 & 238,40 & 29,68 & 643,37 & 0,64 \\
\hline 4 & 2020 & 1,29 & 4,12 & 31,25 & 223,50 & 353,50 & 29,68 & 795,79 & 0,80 \\
\hline 5 & 2023 & 1,40 & 4,18 & 31,68 & 226,60 & 669,62 & 29,68 & $1.210,54$ & 1,21 \\
\hline
\end{tabular}

Tabel 3. Keseimbangan Air Tahun 2016

\begin{tabular}{|c|c|c|c|c|c|c|c|c|c|c|}
\hline \multirow{3}{*}{ Bln } & \multirow{3}{*}{ 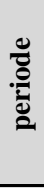 } & \multirow{3}{*}{ hari } & \multirow{3}{*}{$\begin{array}{c}\text { Total } \\
\begin{array}{c}\text { Ketersediaan } \\
\text { Air }\end{array} \\
\mathbf{m}^{3} \\
\end{array}$} & \multicolumn{4}{|c|}{ Kebutuhan Air } & \multirow{3}{*}{$\begin{array}{c}\begin{array}{c}\text { Total } \\
\text { Kebutuhan } \\
\text { Air }\end{array} \\
\mathbf{m}^{3} \\
\end{array}$} & \multirow{2}{*}{\multicolumn{2}{|c|}{ Keseimbangan Air }} \\
\hline & & & & \multicolumn{2}{|c|}{ Domestik } & \multicolumn{2}{|c|}{ Non Domestik } & & & \\
\hline & & & & $\mathrm{m}^{3} / \mathrm{dt}$ & $\mathrm{m}^{3}$ & $\mathrm{~m}^{3} / \mathrm{dt}$ & $\mathrm{m}^{3}$ & & $\mathrm{~m}^{3}$ & Kondisi \\
\hline Jan & 1 & 31 & 71.849 .438 & 1,31 & 3.507 .073 & 0,55 & 1.459 .753 & 4.966 .826 & 66.882 .612 & Surplus \\
\hline Peb & 1 & 28 & 99.428 .466 & 1,31 & 3.167 .679 & 0,55 & 1.318 .486 & 4.486 .166 & 94.942 .300 & Surplus \\
\hline Mar & 1 & 31 & 98.132 .852 & 1,31 & 3.507 .073 & 0,55 & 1.459 .753 & 4.966 .826 & 93.166 .026 & Surplus \\
\hline Apr & 1 & 30 & 32.541 .039 & 1,31 & 3.393 .942 & 0,55 & 1.412 .664 & 4.806 .606 & 27.734 .433 & Surplus \\
\hline Mei & 1 & 31 & 17.293 .883 & 1,31 & 3.507 .073 & 0,55 & 1.459 .753 & 4.966 .826 & 12.327 .057 & Surplus \\
\hline Jun & 1 & 30 & 8.357 .732 & 1,31 & 3.393 .942 & 0,55 & 1.412 .664 & 4.806 .606 & 3.551 .126 & Surplus \\
\hline Jul & 1 & 31 & 4.880 .719 & 1,31 & 3.507 .073 & 0,55 & 1.459 .753 & 4.966 .826 & (86.107) & Defisit \\
\hline Ags & 1 & 31 & 3.008 .784 & 1,31 & 3.507 .073 & 0,55 & 1.459 .753 & 4.966 .826 & (1.958.043) & Defisit \\
\hline Sep & 1 & 30 & 2.233 .621 & 1,31 & 3.393 .942 & 0,55 & 1.412 .664 & 4.806 .606 & $(2.572 .985)$ & Defisit \\
\hline Okt & 1 & 31 & 1.340 .173 & 1,31 & 3.507 .073 & 0,55 & 1.459 .753 & 4.966 .826 & $(3.626 .653)$ & Defisit \\
\hline Nop & 1 & 30 & 3.004 .702 & 1,31 & 3.393 .942 & 0,55 & 1.412 .664 & 4.806 .606 & (1.801.904) & Defisit \\
\hline Des & 1 & 31 & 114.302 .807 & 1,31 & 3.507 .073 & 0,55 & 1.459 .753 & 4.966 .826 & 109.335 .981 & Surplus \\
\hline
\end{tabular}

Tabel 4. Rekapitulasi Rata-rata Defisit Air pada Musim Kemarau (per tahun)

\begin{tabular}{|c|r|r|r|r|c|}
\hline Tahun & $\begin{array}{c}\text { Ketersediaan } \\
\text { Air }(\mathrm{m} 3)\end{array}$ & $\begin{array}{c}\text { Kebutuhan Air } \\
(\mathrm{m} 3)\end{array}$ & $\begin{array}{c}\text { Keseimbangan } \\
\text { Air }(\mathrm{m} 3)\end{array}$ & Kondisi & $\begin{array}{c}\text { Lama } \\
\text { Defisit } \\
(\mathrm{B})\end{array}$ \\
\hline 2016 & 2.893 .600 & 4.902 .738 & $(2.009 .138)$ & Defisit & 5 \\
\hline 2017 & 2.893 .600 & 5.034 .657 & $(2.141 .057)$ & Defisit & 5 \\
\hline 2018 & 2.893 .600 & 5.194 .596 & $(2.300 .996)$ & Defisit & 5 \\
\hline 2020 & 2.893 .600 & 5.629 .730 & $(2.736 .130)$ & Defisit & 5 \\
\hline 2023 & 2.893 .600 & 6.775 .193 & $(3.881 .593)$ & Defisit & 5 \\
\hline
\end{tabular}




\section{Analisa Metode Vegetasi}

Upaya dalam meminimalisir defisit air yang terjadi pada musim kemarau yaitu salah satunya dengan mengembalikan fungsi tata guna lahan seperti fungsi semula, dimana peranan konservasi menjadi alternatifnya. Dalam tesis ini digunakan vegetasi yang memiliki nilai hidrologis dan konservasi serta sesuai dengan topografi dan iklim setempat. Jenis vegetasi yang digunakan adalah pohon gaharu dikarenakan tanaman tersebut memiliki kemampuan menyerap air yang tinggi. Contoh perhitungan:

Vegetasi menggunakan Pohon Gaharu

- Defisit air pada tahun $2016=2.009 .138 \mathrm{~m}^{3}$

- Simpanan lengas tanah $\quad=125 \mathrm{~mm} \sim 0,125 \mathrm{~m}$ Luas lahan yang dibutuhkan:

$$
\begin{aligned}
& \text { Luas Lahan Yang Dibutuhkan }=\frac{\text { Defisit Air }}{\text { Rata-Rata Simpanan }} \\
& \qquad=2.009 .138 \mathrm{~m}^{3} / 0,125 \mathrm{~m} \\
& =9.454 .769 \mathrm{~m}^{2} \sim 945 \mathrm{ha} \sim 9,45 \mathrm{~km}^{2}
\end{aligned}
$$

Dengan menggunakan rumus diatas, kebutuhan lahan untuk vegetasi pada tahun 2017, 2018, 2020 dan 2023 dapat dihitung. Tabel 5. Memperlihatkan kebutuhan luasan lahan untuk konservasi pada tahun 2017, 2018, 2020 dan 2023.

\section{Analisis Metode Mekanis}

\section{Pemanen Air Hujan dengan Atap Bangunan (Roof of Rain Water Harvesting)}

Pemanen air hujan adalah suatu cara mengumpulkan atau menampung air hujan ketika curah hujan tinggi dan kemudian dimanfaatkan saat cuaca hujan rendah atau pun sama sekali tidak turun hujan (Marmoyo, 2015). Teknik pemanenan air hujan dengan atap bangunan pada prinsipnya dilakukan dengan memanfaatkan atap bangunan (rumah) sebagai daerah tangkapan airnya (catchment area).

Heryani (2009) dalam tulisannya yang berjudul "Teknik Panen Hujan", menjelaskan bahwa, potensi jumlah air yang dapat dipanen dari suatu bangunan atap dapat diketahui melalui perhitungan secara sederhana, sebagai berikut:

$\mathrm{Q} \quad=\mathrm{A} \times \mathrm{P} \times \mathrm{C}$

Dimana:

$\mathrm{Q} \quad=$ volume air hujan yang dapat dipanen $\left(\mathrm{m}^{3}\right)$

A $=$ luas area tangkapan hujan $\left(\mathrm{m}^{2}\right)$

$\mathrm{P} \quad=$ curah hujan tahunan $(\mathrm{mm})$

$\mathrm{C}=$ koefisen $\operatorname{runoff}(\%)$

Contoh Perhitungan:

- Area tangkapan hujan dengan luas $=42 \mathrm{~m}^{2}$

- Curah hujan tahunan $=2.122 \mathrm{~mm} /$ tahun $=2,122 \mathrm{~m} /$ tahun

Jumlah air yang dapat dipanen:

$$
\begin{aligned}
\text { - Volume air hujan yang jatuh } & =42 \times 2,122 \\
& =89,12 \mathrm{~m}^{3} / \text { tahun }
\end{aligned}
$$

Dengan asumsi hanya $80 \%$ dari total hujan yang dapat dipanen (20\% hilang karena evapotranspirasi atau kebocoran), maka volume yang dapat dipanen:

$$
\begin{aligned}
& =89,12 \times 80 \% \\
& =71,30 \mathrm{~m}^{3}
\end{aligned}
$$

Jumlah pemanen air hujan:

$$
\begin{array}{ll}
\text { Volume air yang dipanen } & =71,30 \mathrm{~m}^{3} \\
\text { - } \quad \text { Volume tampungan } & =32 \mathrm{~m}^{3} \\
& \text { direncanakan }(4 \times 4 \times 2) \mathrm{m}
\end{array}
$$

maka,

$$
\begin{aligned}
& \text { Jumlah pemanen air hujan }=\frac{\text { Volume Air yang dipanen }}{\text { Volume Tampungan }} \\
& \qquad \begin{aligned}
& 71,30 / 32 \\
& =2,2 \text { buah } \sim 2 \text { buah. }
\end{aligned}
\end{aligned}
$$

Jika diasumsikan rata-rata dalam satu keluarga terdiri dari 5 orang, dengan rata-rata konsumsi 94,87 ltr/org/hari, maka volume air tampungan mampu untuk mencukupi kebutuhan air satu keluarga selama:

$$
\begin{array}{ll}
\text { Lama air tercukupi }=\frac{\text { Volume Air yang dipanen }}{\text { Total Kebutuhan }} \\
\text { - Jumlah Org dlm 1 KK } & =5 \text { Orang } \\
\text { - Kebutuhan Air per Orang } & =94,87 \mathrm{ltr} / \mathrm{org} / \mathrm{hari} \sim \\
& 0,095 \mathrm{~m}^{3} / \mathrm{org} / \mathrm{hari} \\
\text { - Total kebutuhan air } & =0,095 \times 5 \\
& 0,474 \mathrm{~m} 3 / \mathrm{hari} \\
\text { - Jumlah hari dalam } 1 \text { bulan } & =31 \text { hari }
\end{array}
$$

maka, lama air tercukupi:

Vol. Air yg dipanen/Total kebutuhan air

$$
\begin{aligned}
& =71,30 / 0,474 \\
& =150,3 \text { hari } \sim 5 \text { bulan }
\end{aligned}
$$

Karena masa kekeringan di Sub DAS Lesti selama 5 bulan, maka dengan bak tampungan seluas $32 \mathrm{~m}^{3}$ sebanyak 2 buah kebutuhan air domestik dapat terpenuhi.

\section{Pembangunan Embung}

Seperti teknik pemanen air hujan lainnya, embung merupakan solusi terbaik untuk menampung air pada musim kering. Kelebihan curah hujan pada musim hujan ditampung untuk digunakan pada musim kemarau. Pada tesis ini untuk menghitung tampungan embung didasarkan pada 2 hal. Hal tersebut antara lain:

1) Desifit air untuk kebutuhan domestik dan non domestic.

2) Defisit air hanya terhadap kebutuhan domestik dan peternakan.

Berdasarkan Tabel 4 dapat diketahui defisit air tiap tahunnya. Untuk mengatasi masalah tersebut dibutuhkan embung dengan volume tampungan sebesar defisit air tiap tahun. Untuk menghitung volume tampungan yang diperlukan berdasarkan kebutuhan air (defisit air) (Vn) adalah:

$$
\begin{array}{ll}
\mathrm{Vn} & =\mathrm{Vu}+\mathrm{Ve}+\mathrm{Vi}+\mathrm{Vs} \\
\mathrm{Vi} & =\mathrm{K} \times \mathrm{Vu} \\
\mathrm{Vs} & =0,05 \times \mathrm{Vu}
\end{array}
$$

Dimana:

Vn =Volume tampungan berdasarkan defisit air $\left(\mathrm{m}^{3}\right)$

$\mathrm{Vu} \quad=$ Volume tampungan hidup untuk melayani defisit $\left(\mathrm{m}^{3}\right)$

Ve $\quad=$ Jumlah penguapan dari kolam selama musim kemarau $\left(\mathrm{m}^{3}\right)$

$\mathrm{Vi} \quad=$ Jumlah resapan melalui dasar dinding dan tubuh embung selama musim kemarau $\left(\mathrm{m}^{3}\right)$

Vs =Ruangan yang disediakan untuk sedimen $\left(\mathrm{m}^{3}\right)$

$\mathrm{K} \quad$ =Faktor yang nilainya tergantung dari sifat lolos air material dasar dan dinding kolam embung, nilai $\mathrm{K}=10 \%$ bila dasar dan dinding kolam 
embung rapat air $\left(\mathrm{K}<10^{\wedge}-5 \mathrm{~cm} / \mathrm{dt}\right)$; nilai $\mathrm{K}=25 \%$ bila dasar dan dinding kolam embung semi lolos air $\left(\mathrm{K}=10^{\wedge}-3 \mathrm{~s} / \mathrm{d} 10^{\wedge}-4 \mathrm{~cm} / \mathrm{dt}\right)$.

1) Perhitungan Volume Tampungan Embung terhadap Desifit Air (kebutuhan domestik dan non domestik).

Volume tampungan hidup ( $\mathrm{Vu}$ ) untuk melayani defisit (Tabel 4), pada tahun $2016=2.009 .138 \mathrm{~m}^{3}$. Jumlah Penguapan dari kolam selama musim kering. Penguapan selama musim kemarau perlu diperhitungkan dalam penentuan volume embung. Untuk mengetahui jumlah penguapan dikolam embung dengan persamaan:

Dimana:

$\mathrm{Ve} \quad=10 \times$ Akt $\times \sum \mathrm{kj}$

$\mathrm{Ve}=$ Jumlah penguapan dari kolam embung selama musim kering $\left(\mathrm{m}^{3}\right)$

Akt =Luasan permukaan kolam embung pada setengah tinggi (ha)

$\sum \mathrm{kj}=$ Penguapan bulanan di musim kemarau $(\mathrm{mm} / \mathrm{bln})$

Berdasarkan nilai penguapan pada Tabel 6, tertera hasil analisa penguapan selama bulan kering. Bulan kering tersebut mulai bulan Juli sampai Nopember. Tabel 7 adalah penguapan pada bulan kering. Dengan persamaan diatas dapat diketahui volume penguapan. Tabel 8 adalah volume penguapan pada bulan kering.

Berdasarkan hasil perhitungan dalam Tabel 8 dapat diketahui bahwa Volume Penguapan Sebesar $985.470 \mathrm{~m}^{3}$.

- Jumlah resapan melalui dasar dan dinding embung $(\mathrm{Vi})=0$

Untuk resapan dianggap 0, karena dasar dan dinding embung dilapisi geotextile sehingga tidak ada air yang meresap.

- Ruangan yang disediakan untuk sedimen (Ve)

Direncanakan ruang sedimen 5\% dari Volume hidup embung $(\mathrm{Vu})$

$$
\begin{array}{ll}
\mathrm{Ve} & =0,05 \times 2.009 .138 \mathrm{~m}^{3} \\
\mathrm{Ve} & =100.457 \mathrm{~m}^{3}
\end{array}
$$

Maka, volume kolam embung berdasarkan kebutuhan air (defisit air) (Vn) pada tahun 2016 sebesar:

$$
\begin{aligned}
\mathrm{Vn} & =\mathrm{Vu}+\mathrm{Ve}+\mathrm{Vi}+\mathrm{Vs} \\
& =2.009 .138+985.470+0+100.457 \\
& =3.095 .056 \mathrm{~m}^{3} .
\end{aligned}
$$

Tabel 9. memperlihatkan kebutuhan volume kolam embung pada tahun 2016, 2017, 2018, 2020 dan 2023. Untuk memenuhi volume total embung seperti pada Tabel 9 maka, dapat direncanakan dimensi embung dan jumlah kebutuhannya.

Contoh Perhitungan, untuk tahun 2016:

$$
\begin{array}{ll}
\text { - Direncanakan dimensi } & =(500 \times 400 \times 4) \mathrm{m} \\
\text { - Volume Embung rencana } & =(500 \times 400 \times 4) \mathrm{m} \\
& =800.000 \mathrm{~m}^{3}
\end{array}
$$

- Vol. Total Embung $\quad=3.095 .065 \mathrm{~m}^{3}$ (Tabel 9)
Kebutuhan Embung

$=$ Vol. Total Embung / Vol. Embung Renc.

$=3.095 .065 / 800.000$

$$
=4 \text { Buah }
$$

- Luas lahan yang dibutuhkan $\quad=(500 \times 400) \mathrm{m}$

$$
=200.000 \mathrm{~m}^{2} \sim 20 \text { ha }
$$

Total Luas lahan yang dibutuhkan $=20 \times 4=80$ ha

Maka berdasarkan hitungan tersebut dapat diketahui untuk memenuhi defisit air pada tahun 2016 dibutuhkan embung sebanyak 4 buah dengan total luas kebutuhan 80 ha. Tabel 10 akan menunjukkan kebutuhan embung tiap tahunnya (2016, 2017,2018, 2020 dan 2023).

\section{2) Perhitungan Volume Tampungan Embung terhadap Defisit Air (kebutuhan domestik dan peternakan).}

Dengan perhitungan yang sama, namun yang membedakan adalah volume tampungan hidup embung didasarkan pada disifir air untuk kebutuhan domestik dan peternakan. Tabel 11 memperlihatkan defisit air tersebut.

Berdasarkan hasil perhitungan dalam Tabel 8 dapat diketahui bahwa Volume Penguapan Sebesar $985.470 \mathrm{~m}^{3}$.

- Jumlah resapan melalui dasar dan dinding embung $(\mathrm{Vi})=0$

Untuk resapan dianggap 0 , karena dasar dan dinding embung dilapisi geotextile sehingga tidak ada air yang meresap.

- Ruangan yang disediakan untuk sedimen $(\mathrm{Ve})$

Direncanakan ruang sedimen 5\% dari Volume hidup embung $(\mathrm{Vu})$

$$
\begin{array}{ll}
\mathrm{Ve} & =0,05 \times 1.488 .377 \mathrm{~m}^{3} \\
\mathrm{Ve} & =74.419 \mathrm{~m}^{3}
\end{array}
$$

Maka, volume kolam embung berdasarkan kebutuhan air (defisit air) (Vn) pada tahun 2016 (Tabel 11) sebesar:

$$
\begin{aligned}
\mathrm{Vn} & =\mathrm{Vu}+\mathrm{Ve}+\mathrm{Vi}+\mathrm{Vs} \\
& =1.488 .377+74.419+0+985.470 \\
& =2.548 .266 \mathrm{~m}^{3}
\end{aligned}
$$

Tabel 12 akan memperlihatkan kebutuhan volume kolam embung pada tahun 2016, 2017, 2018, 2020 dan 2023.

Untuk memenuhi volume total embung seperti pada Tabel 12 maka dapat direncanakan dimensi embung dan jumlah kebutuhannya.

Contoh Perhitungan, untuk tahun 2016:

$$
\begin{array}{rlr}
-\quad \text { Direncanakan dimensi } & =(500 \times 4004) \mathrm{m} \\
\text { - } \quad \text { Vol. Embung rencana } & =(500 \times 400 \times 4) \mathrm{m} \\
& & =800.000 \mathrm{~m}^{3} \\
\text { - } & \text { Vol.Total Embung }=2.548 .266 \mathrm{~m}^{3}(\text { Tabel 12) }
\end{array}
$$

Kebutuhan Embung

$$
\begin{aligned}
& =\text { Vol. Total Embung / Vol. Embung Renc. } \\
& =2.548 .266 / 800.000 \\
& =3 \text { Buah }
\end{aligned}
$$

Luas lahan yang dibutuhkan $\quad=(500 \times 400) \mathrm{m}$

$$
=200.000 \mathrm{~m}^{2} \sim 20 \mathrm{ha}
$$

Total Luas lahan yang dibutuhkan $=20 \times 3=64$ ha 
Tabel 5. Kebutuhan Lahan untuk Konservasi Vegetasi (Pohon Gaharu)

\begin{tabular}{|c|c|r|r|r|r|r|}
\hline \multirow{2}{*}{ Tahun } & Defisit Air & \multicolumn{2}{|c|}{$\begin{array}{c}\text { Kedalaman } \\
\text { Akar }\end{array}$} & $\begin{array}{c}\text { Kapasitas } \\
\text { Simpanan } \\
\text { Air }\end{array}$ & \multicolumn{1}{c|}{$\begin{array}{c}\text { Simpanan } \\
\text { Lengas } \\
\text { Tanah }(\mathrm{mm})\end{array}$} & \multicolumn{2}{|c|}{ Kebutuhan Lahan } \\
\cline { 2 - 7 }$(\mathrm{m} 3)$ & $(\mathrm{m})$ & $(\mathrm{mm} / \mathrm{m})$ & $(\mathrm{mm})$ & $\left(\mathrm{m}^{2}\right)$ & $\left(\mathrm{km}^{2}\right)$ \\
\hline 2016 & 2.009 .138 & 1,70 & 125,00 & 212,50 & 9.454 .769 & 9,45 \\
\hline 2017 & 2.141 .057 & 1,70 & 125,00 & 212,50 & 10.075 .565 & 10,08 \\
\hline 2018 & 2.300 .996 & 1,70 & 125,00 & 212,50 & 10.828 .217 & 10,83 \\
\hline 2020 & 2.736 .130 & 1,70 & 125,00 & 212,50 & 12.875 .907 & 12,88 \\
\hline 2023 & 3.881 .593 & 1,70 & 125,00 & 212,50 & 18.266 .320 & 18,27 \\
\hline
\end{tabular}

Tabel 6. Nilai Evapotranspirasi Potensial Total di Sub DAS Lesti

\begin{tabular}{|c|c|c|c|c|c|c|c|c|c|c|c|c|}
\hline TH & JAN & PEB & MAR & APR & MEI & JUN & JUL & AGT & SEP & OKT & NOP & DES \\
\hline \hline 2003 & 109,45 & 99,41 & 108,06 & 107,61 & 102,21 & 89,89 & 72,91 & 85,12 & 96,05 & 111,72 & 112,90 & 106,79 \\
\hline 2004 & 109,06 & 99,07 & 100,06 & 108,59 & 103,09 & 85,05 & 88,22 & 82,44 & 95,64 & 115,43 & 119,41 & 111,68 \\
\hline 2005 & 110,15 & 101,28 & 110,09 & 102,06 & 101,60 & 97,33 & 87,92 & 87,65 & 100,22 & 113,86 & 109,70 & 103,49 \\
\hline 2006 & 111,98 & 95,76 & 105,36 & 102,51 & 100,86 & 81,09 & 80,90 & 78,54 & 85,67 & 114,28 & 129,52 & 125,90 \\
\hline 2007 & 110,71 & 98,17 & 104,17 & 102,58 & 104,64 & 92,08 & 85,30 & 80,74 & 90,21 & 117,05 & 108,91 & 109,34 \\
\hline 2008 & 108,49 & 97,37 & 99,65 & 100,52 & 96,55 & 84,84 & 78,43 & 85,57 & 96,41 & 121,46 & 113,18 & 105,88 \\
\hline 2009 & 106,04 & 95,16 & 106,02 & 108,31 & 105,27 & 90,19 & 83,30 & 86,36 & 96,44 & 116,51 & 121,99 & 118,26 \\
\hline 2010 & 109,26 & 99,83 & 113,68 & 101,91 & 113,14 & 98,20 & 94,77 & 98,08 & 101,24 & 110,95 & 114,45 & 110,59 \\
\hline 2011 & 114,67 & 100,79 & 102,30 & 98,09 & 101,53 & 81,82 & 83,10 & 83,02 & 91,89 & 115,67 & 110,95 & 114,55 \\
\hline 2012 & 107,00 & 96,10 & 107,44 & 102,49 & 102,86 & 87,56 & 79,27 & 80,35 & 93,76 & 119,77 & 119,84 & 112,37 \\
\hline 2013 & 106,44 & 91,07 & 100,19 & 89,56 & 101,80 & 95,25 & 79,09 & 89,47 & 91,23 & 107,32 & 105,93 & 110,25 \\
\hline
\end{tabular}

Tabel 7. Pengguapan pada Musim Kemarau

\begin{tabular}{|c|l|c|}
\hline No & \multicolumn{1}{|c|}{ Bulan } & $\begin{array}{c}\text { Penguapan (rata-rata) } \\
\text { mm/bulan }\end{array}$ \\
\hline 1 & Juli & 83,02 \\
\hline 2 & Agustus & 85,21 \\
\hline 3 & September & 94,43 \\
\hline 4 & Oktober & 114,91 \\
\hline 5 & Nopember & 115,16 \\
\hline
\end{tabular}

Tabel 8. Volume Penguapan Kolam Embung

\begin{tabular}{|c|l|c|r|r|c|}
\hline \multirow{2}{*}{ No } & \multirow{2}{*}{ Bulan } & $\begin{array}{c}\text { Luas } \\
\text { Genangan }\end{array}$ & \multicolumn{2}{c|}{ Penguapan (rata-rata) } & $\begin{array}{c}\text { Volume } \\
\text { Penguapan }\end{array}$ \\
\cline { 3 - 6 } & & $(\mathrm{m} 2)$ & $(\mathrm{mm} /$ bulan $)$ & $(\mathrm{m} /$ bulan $)$ & $(\mathrm{m} 3)$ \\
\hline 1 & Juli & 200.000 & 83,02 & 0,083 & 166.039 \\
\hline 2 & Agustus & 200.000 & 85,21 & 0,085 & 170.426 \\
\hline 3 & September & 200.000 & 94,43 & 0,094 & 188.863 \\
\hline 4 & Oktober & 200.000 & 114,91 & 0,115 & 229.819 \\
\hline 5 & Nopember & 200.000 & 115,16 & 0,115 & 230.323 \\
\hline & \multicolumn{5}{|c|}{ Jumlah Volume Penguapan } \\
\hline
\end{tabular}


Maka berdasarkan hitungan tersebut dapat diketahui untuk memenuhi defisit air pada tahun 2016 dibutuhkan embung sebanyak 4 buah dengan total luas kebutuhan 80 ha. Tabel 10 akan menunjukkan kebutuhan embung tiap tahunnya (2016, 2017,2018, 2020 dan 2023).

\section{3) Perhitungan Volume Tampungan Embung terhadap Defisit Air (kebutuhan domestik dan peternakan).}

Dengan perhitungan yang sama, namun yang membedakan adalah volume tampungan hidup embung didasarkan pada disifir air untuk kebutuhan domestik dan peternakan. Tabel 11 memperlihatkan defisit air tersebut. Berdasarkan hasil perhitungan dalam Tabel 8 dapat diketahui bahwa Volume Penguapan Sebesar $985.470 \mathrm{~m}^{3}$.

- Jumlah resapan melalui dasar dan dinding embung $(\mathrm{Vi})=0$

Untuk resapan dianggap 0, karena dasar dan dinding embung dilapisi geotextile sehingga tidak ada air yang meresap.

- Ruangan yang disediakan untuk sedimen (Ve)

Direncanakan ruang sedimen 5\% dari Volume hidup embung $(\mathrm{Vu})$

$\mathrm{Ve} \quad=0,05 \times 1.488 .377 \mathrm{~m}^{3}$

$\mathrm{Ve} \quad=74.419 \mathrm{~m}^{3}$

Maka, volume kolam embung berdasarkan kebutuhan air (defisit air) (Vn) pada tahun 2016 (Tabel 11) sebesar:

$$
\begin{aligned}
\mathrm{Vn} & =\mathrm{Vu}+\mathrm{Ve}+\mathrm{Vi}+\mathrm{Vs} \\
& =1.488 .377+74.419+0+985.470 \\
& =2.548 .266 \mathrm{~m}^{3}
\end{aligned}
$$

Tabel 12 akan memperlihatkan kebutuhan volume kolam embung pada tahun 2016, 2017, 2018, 2020 dan 2023. Untuk memenuhi volume total embung seperti pada Tabel 12 maka dapat direncanakan dimensi embung dan jumlah kebutuhannya. Contoh Perhitungan, untuk tahun 2016:

- Direncanakan dimensi

$$
\begin{aligned}
& =(500 \times 400 \times 4) \mathrm{m} \\
& =(500 \times 400 \times 4) \mathrm{m} \\
& =800.000 \mathrm{~m}^{3} \\
& =2.548 .266 \mathrm{~m}^{3}
\end{aligned}
$$

(Tabel 12)

Kebutuhan Embung

$$
\begin{aligned}
& =\text { Vol. Total Embung / Vol. Embung Renc. } \\
& =2.548 .266 / 800.000 \\
& =3 \text { Buah }
\end{aligned}
$$

Luas lahan yang dibutuhkan $\quad=(500 \times 400) \mathrm{m}$

$$
=200.000 \mathrm{~m}^{2} \sim 20 \text { ha }
$$

Total Luas lahan yang dibutuhkan $=20 \times 3=64$ ha

Maka berdasarkan hitungan tersebut dapat diketahui untuk memenuhi defisit air pada tahun 2016 dibutuhkan embung sebanyak 3 buah dengan total luas kebutuhan 64 ha. Tabel 13 akan menunjukkan kebutuhan embung tiap tahunnya (2016, 2017,2018, 2020 dan 2023).

Pada tesis ini kebutuhan embung yang digunakan adalah untuk keperluan domestik dan peternakan, dikarenakan kebutuhan tersebut yang paling dibutuhkan di wilayah studi.

\section{Analisis Finansial}

\section{Biaya Investasi}

Biaya modal/investasi terdiri dari 2 macam yaitu biaya langsung dan biaya tak langsung. Biaya langsung antara lain: biaya administrasi dan biaya konsultan. Biaya tak langsung antara lain: perubahan desain, fluktuasi harga bahan berdasarkan hasil studi pembuatan embung kucur-kucur di kabupaten Kediri pada tahun 2012 dengan kapasitas tampung $76.122 \mathrm{~m}^{3}$, biaya konstruksi Rp. 6.355.940.000,-. Dari data tersebut dapat diketahui harga rata-rata per meter kubiknya adalah Rp. 83.497,. Jika dengan tingkat inflasi pada tahun 2015 sebesar 3,4\% (Bank Indonesia, 2015) maka harga rata-rata per kubiknya pada menjadi Rp.86.336,-. Pada tesis ini pemanfaatan embung hanya untuk pemenuhan kebutuhan domestik dan peternakan pada musim kemarau. Berdasarkan Tabel 13 diketahui jumlah kebutuhan embung pada tahun 2017 s/d 2018 sebanyak 3 unit dengan kapasitas tampungan $800.000 \mathrm{~m}^{3}$. Jika harga per $\mathrm{m}^{3}$ adalah Rp.86.336 maka dengan luas $800.000 \mathrm{~m}^{3}$ biaya konstruksi nya sebesar Rp. 69.068.515.900 per embung, jika butuh 3 embung menjadi Rp. 207.205.545.000,-. Tabel 14 memperlihatkan biaya investasi yang terdiri dari biaya langsung dan biaya tidak langsung. Biaya investasi untuk membangun embung 3 buah yang dilakukan dari tahun 2017 s/d 2018 sebesar Rp. 264.187.069.875,-. Perhitungan biaya O\&P tiap tahun $2 \%$ dari Biaya Konstruksi, menjadi Rp. 4.144.110.900,

\section{Analisis Manfaat}

Manfaat/keuntungan per tahun dari pembangunan embung ini dapat dihitung dengan biaya investasi dikonfersi dengan nilai suku bunga bank. Dalam penelitian ini nilai suku bunga bank pinjaman yang digunakan sebesar 11\% (Bank Indonesia, 2016). Perhitungan keuntungan pertahun dapat dilihat pada Tabel 15. Dengan menggunakan aplikasi Excel perhitungan BCR, NPV dan IRR dapat dilakukan dengan lebih mudah. Untuk mendapatkan ukuran yang menyeluruh sebagai dasar penilaian kelayakan proyek pembangunan dibutuhkan kriteria tertentu.

Kriteria-kriteria yang umum dan dianjurkan dalam evaluasi kelayakan proyek (indokator kelayakan financial) adalah:

- $\quad$ Benefit Cost Ratio (BCR) > 1

- Net Present Value (NPV)

- Internal Rate of Return (IRR) $>11 \%$ (suku bunga bank pinjaman)

Dengan melihat Tabel 16 dapat diketahui pembangunan 3 embung yang dikerjakan pada tahun 2017 sampai 2018 dengan suku bunga bank pinjaman 11\% pertahun nilai IRR sebesar 13,89\% > 11\%; BCR, i (11\%) $=1,14>1$ dan NPV, i (11\%) Rp. 40.390.322.590,-. Dari hasil tersebut dapat disimpulkan bahwa pembangunan 3 embung tersebut secara finansial layak dilaksanakan. 
Tabel 9. Volume Kolam Embung (Kebutuhan Domestik + Non Domestik)

\begin{tabular}{|c|c|c|c|c|c|}
\hline Tahun & $\begin{array}{c}\text { Volume Hidup } \\
\text { Embung (Vu) }\end{array}$ & $\begin{array}{c}\text { Volume Ruang } \\
\text { Sedimen (Ve) }\end{array}$ & $\begin{array}{c}\text { Volume } \\
\text { Resapan } \\
(\text { Vi) }\end{array}$ & $\begin{array}{c}\text { Volume } \\
\text { Penguapan } \\
(\text { Vs) }\end{array}$ & $\begin{array}{c}\text { Volume Total } \\
\text { Embung (Vn) }\end{array}$ \\
\cline { 2 - 6 } & $(\mathrm{m} 3)$ & $(\mathrm{m} 3)$ & $(\mathrm{m} 3)$ & $(\mathrm{m} 3)$ & $(\mathrm{m} 3)$ \\
\hline 2016 & 2.009 .138 & 100.457 & 0 & 985.470 & 3.095 .065 \\
\hline 2017 & 2.141 .057 & 107.053 & 0 & 985.470 & 3.233 .581 \\
\hline 2018 & 2.300 .996 & 115.050 & 0 & 985.470 & 3.401 .516 \\
\hline 2020 & 2.736 .130 & 136.807 & 0 & 985.470 & 3.858 .407 \\
\hline 2023 & 3.881 .593 & 194.080 & 0 & 985.470 & 5.061 .143 \\
\hline
\end{tabular}

Tabel 10. Kebutuhan Embung (Kebutuhan Domestik + Non Domestik)

\begin{tabular}{|c|c|c|c|c|c|c|c|c|}
\hline \multirow{2}{*}{ Tahun } & $\mathrm{P}$ & $\mathrm{L}$ & $\mathrm{T}$ & $\begin{array}{c}\text { Vol. } \\
\text { Embung } \\
\text { Rencana }\end{array}$ & $\begin{array}{c}\text { Volume Total } \\
\text { Embung (yg } \\
\text { dibutuhkan) }\end{array}$ & $\begin{array}{c}\text { Kebutuhan } \\
\text { Embung }\end{array}$ & $\begin{array}{c}\text { Luas } \\
\text { Lahan }\end{array}$ & $\begin{array}{c}\text { Kebutuhan } \\
\text { Luas Lahan } \\
\text { Total }\end{array}$ \\
\cline { 2 - 9 } & $(\mathrm{m})$ & $(\mathrm{m})$ & $(\mathrm{m})$ & $(\mathrm{m} 3)$ & $(\mathrm{m} 3)$ & (unit) & (ha) & (ha) \\
\hline 2016 & 500 & 400 & 4,0 & 800.000 & 3.095 .065 & 4 & 20 & 80 \\
\hline 2017 & 500 & 400 & 4,0 & 800.000 & 3.233 .581 & 4 & 20 & 80 \\
\hline 2018 & 500 & 400 & 4,0 & 800.000 & 3.401 .516 & 4 & 20 & 80 \\
\hline 2020 & 500 & 400 & 4,0 & 800.000 & 3.858 .407 & 5 & 20 & 100 \\
\hline 2023 & 500 & 400 & 4,0 & 800.000 & 5.061 .143 & 6 & 20 & 120 \\
\hline
\end{tabular}

Tabel 11. Defisit Air terhadap Kebutuhan Domestik dan Peternakan

\begin{tabular}{|c|c|c|c|c|c|}
\hline Tahun & $\begin{array}{c}\text { Ketersediaan } \\
\text { Air }(\mathrm{m} 3)\end{array}$ & $\begin{array}{c}\text { Kebutuhan } \\
\text { Air }(\mathrm{m} 3)\end{array}$ & $\begin{array}{c}\text { Keseimbangan } \\
\text { Air }(\mathrm{m} 3)\end{array}$ & Kondisi & $\begin{array}{c}\text { Lama } \\
\text { Defisit }\end{array}$ \\
\hline 2016 & 2.396 .820 & 3.885 .197 & $(1.488 .377)$ & Defisit & 4 \\
\hline 2017 & 2.396 .820 & 3.987 .051 & $(1.590 .231)$ & Defisit & 4 \\
\hline 2018 & 2.396 .820 & 4.110 .442 & $(1.713 .622)$ & Defisit & 4 \\
\hline 2020 & 2.396 .820 & 4.445 .812 & $(2.048 .992)$ & Defisit & 4 \\
\hline 2023 & 2.396 .820 & 5.327 .609 & $(2.930 .789)$ & Defisit & 5 \\
\hline
\end{tabular}

Tabel 12. Volume Kolam Embung (Kebutuhan Domestik dan Peternakan)

\begin{tabular}{|c|l|r|r|r|c|}
\hline \multirow{2}{*}{ No } & \multirow{2}{*}{ Bulan } & $\begin{array}{c}\text { Luas } \\
\text { Genangan }\end{array}$ & \multicolumn{2}{c|}{ Penguapan (rata-rata) } & $\begin{array}{c}\text { Volume } \\
\text { Penguapan }\end{array}$ \\
\cline { 3 - 6 } & & $(\mathrm{m} 2)$ & $(\mathrm{mm} / \mathrm{bulan})$ & $(\mathrm{m} /$ bulan $)$ & $(\mathrm{m} 3)$ \\
\hline 1 & Juli & 200.000 & 83,02 & 0,083 & 166.039 \\
\hline 2 & Agustus & 200.000 & 85,21 & 0,085 & 170.426 \\
\hline 3 & September & 200.000 & 94,43 & 0,094 & 188.863 \\
\hline 4 & Oktober & 200.000 & 114,91 & 0,115 & 229.819 \\
\hline 5 & Nopember & 200.000 & 115,16 & 0,115 & 230.323 \\
\hline & \multicolumn{5}{|c|}{ Jumlah Volume Penguapan } \\
\hline
\end{tabular}

Tabel 13. Kebutuhan Embung (Kebutuhan Domestik dan Peternakan)

\begin{tabular}{|c|c|c|c|c|c|c|c|c|}
\hline \multirow{2}{*}{ Tahun } & $\mathrm{P}$ & $\mathrm{L}$ & $\mathrm{T}$ & $\begin{array}{c}\text { Vol. } \\
\text { Embung } \\
\text { Rencana }\end{array}$ & $\begin{array}{c}\text { Volume Total } \\
\text { Embung (yg } \\
\text { dibutuhkan) }\end{array}$ & $\begin{array}{c}\text { Kebutuhan } \\
\text { Embung }\end{array}$ & $\begin{array}{c}\text { Luas } \\
\text { Lahan }\end{array}$ & $\begin{array}{c}\text { Kebutuhan } \\
\text { Luas Lahan } \\
\text { Total }\end{array}$ \\
\cline { 2 - 9 } & $(\mathrm{m})$ & $(\mathrm{m})$ & $(\mathrm{m})$ & $(\mathrm{m} 3)$ & $(\mathrm{m} 3)$ & (unit) & (ha) & (ha) \\
\hline 2016 & 500 & 400 & 4,0 & 800.000 & 2.548 .266 & 3 & 20 & 64 \\
\hline 2017 & 500 & 400 & 4,0 & 800.000 & 2.655 .213 & 3 & 20 & 66 \\
\hline 2018 & 500 & 400 & 4,0 & 800.000 & 2.784 .773 & 3 & 20 & 70 \\
\hline 2020 & 500 & 400 & 4,0 & 800.000 & 3.136 .912 & 4 & 20 & 78 \\
\hline 2023 & 500 & 400 & 4,0 & 800.000 & 4.062 .798 & 5 & 20 & 102 \\
\hline
\end{tabular}


Tabel 14. Biaya Investasi Pembuatan Embung

\begin{tabular}{|c|c|c|c|}
\hline No & \multicolumn{2}{|r|}{ Uraian } & Jumlah \\
\hline \multirow[t]{3}{*}{1} & \multicolumn{2}{|c|}{ Biaya Langsung } & \\
\hline & \begin{tabular}{|l|l|} 
& 1.1 \\
\end{tabular} & Biaya Konstruksi & 207.205 .545 .000 \\
\hline & & Total Biaya Langsung & 207.205 .545 .000 \\
\hline \multirow[t]{7}{*}{2} & \multicolumn{2}{|c|}{ Biaya Tak Langsung } & \\
\hline & \begin{tabular}{l|r|} 
& 2.1 \\
\end{tabular} & Contigencies, $5 \%$ Biaya Langsung & 10.360 .277 .250 \\
\hline & 2.2 & $\begin{array}{l}\text { Biaya Teknik (Desain + Supervisi) } 10 \% \text { Biaya } \\
\text { Langsung }\end{array}$ & 20.720 .554 .500 \\
\hline & 2.3 & Pajak, $10 \%$ Biaya Langsung & 20.720 .554 .500 \\
\hline & 2.4 & Biaya Administrasi, 2,5\% Biaya Langsung & 5.180 .138 .625 \\
\hline & 2.5 & Pembebasan Lahan & - \\
\hline & & Total Biaya Tidak Langsung & 56.981 .524 .875 \\
\hline \multirow[t]{4}{*}{3} & \multicolumn{2}{|c|}{ Biaya Investasi } & \\
\hline & \begin{tabular}{|l|l|} 
& 3.1 \\
\end{tabular} & Biaya Langsung & 207.205 .545 .000 \\
\hline & 3.2 & Biaya Tidak Langsung & 56.981 .524 .875 \\
\hline & & Total Biaya Investasi & 264.187 .069 .875 \\
\hline
\end{tabular}

Tabel 15. Perhitungan Keuntungan Per Tahun

\begin{tabular}{|c|c|c|c|}
\hline $\mathrm{a}$ & Biaya Proyek & $264.187 .069 .875,00$ & \\
\hline $\mathrm{b}$ & $\mathrm{F} / \mathrm{P}, 11 \%, 1$ & 1,110 & \\
\hline $\mathrm{c}$ & $\mathrm{A} / \mathrm{P}, 11 \%, 20$ & 0,125 & \\
\hline $\mathrm{d}$ & Sub total $(\mathrm{a} \times \mathrm{b} \times \mathrm{c})$ & & 36.655 .955 .945 \\
\hline $\mathrm{e}$ & Biaya O \& P & & 4.144 .110 .900 \\
\hline $\mathrm{f}$ & Total $(\mathrm{d}+\mathrm{e})$ & & 40.800 .066 .845 \\
\hline $\mathrm{g}$ & Produksi Air baku (m²/tahun) & $2.662 .750,87$ & \\
\hline $\mathrm{h}$ & Nilai air/m ${ }^{3} \quad(\mathrm{f} / \mathrm{g})$ & & $16.677,00$ \\
\hline $\mathrm{i}$ & Nilai air/ltr & & 16,68 \\
\hline $\mathrm{j}$ & Keuntungan air pertahun $(\mathrm{g} \times \mathrm{h})$ & & 44.406 .696 .274 \\
\hline
\end{tabular}

Tabel 16. Nilai BCR, NPV dan IRR

ANALISA KELAYAKAN FINANSIAL

EMBUNG Sub DAS Lesti

\begin{tabular}{|c|c|c|c|c|}
\hline \multicolumn{5}{|c|}{$\begin{array}{l}\text { Tahun Pelaksanaan: } \\
\text { Annual Cost : }\end{array}$} \\
\hline & \multicolumn{2}{|c|}{264.187 .069 .875} & \multirow{2}{*}{$\begin{array}{l}\text { Biaya O \& P } \\
\text { Benefit airbaku } \\
\text { Umur Konstruksi (th) }\end{array}$} & $\begin{array}{l}=\text { Rp. } 4 \cdot 144 \cdot 110.900 \\
=\text { Rp. } 44.406 .696 .274\end{array}$ \\
\hline & & & & \\
\hline $\begin{array}{c}\text { Tahun } \\
\text { ke- }\end{array}$ & $\begin{array}{c}\text { Investasi } \\
(\mathrm{Rp})\end{array}$ & $\begin{array}{l}\text { Biaya O \& P } \\
(\mathrm{RP})\end{array}$ & \begin{tabular}{|c|}
$\begin{array}{c}\text { Manfaat } \\
(\mathrm{Rp})\end{array}$ \\
\end{tabular} & $\begin{array}{c}\text { Manfaat Bersih } \\
(\mathrm{Rp})\end{array}$ \\
\hline 0 & 264.187 .069 .875 & & 0 & \\
\hline 1 & & & & $(264.187 .069 .875)$ \\
\hline 2 & & 4.144 .110 .900 & 44.406.696.274 & 40.262 .585 .374 \\
\hline 3 & & 4.144 .110 .900 & 44.406.696.274 & 40.262 .585 .374 \\
\hline 4 & & 4.144 .110 .900 & 44.406.696.274 & 40.262 .585 .374 \\
\hline 5 & & 4.144 .110 .900 & 44.406.696.274 & 40.262 .585 .374 \\
\hline 6 & & 4.351 .316 .445 & 44.406 .696 .274 & 40.055 .379 .829 \\
\hline 7 & & 4.351 .316 .445 & 44.406.696.274 & 40.055 .379 .829 \\
\hline 8 & & 4.351 .316 .445 & 44.406.696.274 & 40.055 .379 .829 \\
\hline 9 & & 4.351 .316 .445 & 44.406.696.274 & 40.055 .379 .829 \\
\hline 10 & & 4.351 .316 .445 & 44.406 .696 .274 & 40.055 .379 .829 \\
\hline 11 & & 4.568.882.267 & 44.406.696.274 & 39.837 .814 .007 \\
\hline 12 & & 4.568 .882 .267 & 44.406 .696 .274 & 39.837.814.007 \\
\hline 13 & & 4.568 .882 .267 & 44.406.696.274 & 39.837 .814 .007 \\
\hline 14 & & 4.568 .882 .267 & 44.406.696.274 & 39.837.814.007 \\
\hline 15 & & 4.568.882.267 & 44.406.696.274 & 39.837 .814 .007 \\
\hline 16 & & 4.797.326.381 & 44.406 .696 .274 & 39.609 .369 .893 \\
\hline 17 & & 4.797.326.381 & 44.406.696.274 & 39.609 .369 .893 \\
\hline 18 & & 4.797 .326 .381 & 44.406.696.274 & 39.609 .369 .893 \\
\hline 19 & & 4.797.326.381 & 44.406.696.274 & 39.609 .369 .893 \\
\hline 20 & & 4.797.326.381 & 44.406.696.274 & 39.609 .369 .893 \\
\hline \multicolumn{4}{|c|}{ Economic Internal Rate of Return (EIRR) } & $13,89 \%$ \\
\hline \multicolumn{4}{|c|}{$\begin{array}{l}\text { Net Present Value (NPV, } \mathrm{i}=10 \%) \\
\text { Net Present Value }(\mathbf{N P V}, \mathbf{i}=\mathbf{1 1} \%) \\
\text { Net Present Value (NPV, } \mathrm{i}=12 \%) \\
\text { Net Present Value (NPV, } \mathrm{i}=14 \%)\end{array}$} & $\begin{array}{r}58.458 .513 .224,17 \\
\mathbf{4 0 . 3 9 0 . 3 2 2 . 5 9 0 , 9 2} \\
24.608 .958 .054,24 \\
(1.292 .744 .914,09)\end{array}$ \\
\hline \multicolumn{4}{|c|}{$\begin{array}{l}\text { Benefit Cost Ratio (BCR, } \mathrm{i}=10 \%) \\
\text { Benefit Cost Ratio }(B C R, \mathrm{i}=\mathbf{1 1} \%) \\
\text { Benefit Cost Ratio }(B C R, \mathrm{i}=12 \%) \\
\text { Benefit Cost Ratio }(B C R, i=14 \%)\end{array}$} & $\begin{array}{r}1,14 \\
\mathbf{1 , 0 5} \\
1,00 \\
0,88\end{array}$ \\
\hline
\end{tabular}




\section{KESIMPULAN}

Berdasarkan hasil analisa, dapat disimpulkan sebagai berikut:

1. Defisit air terhadap kebutuhan domestik dan non domestik di Sub DAS Lesti terjadi selama 5 bulan (bulan kering), yaitu bulan Juli sampai Nopember. Defisit air terhadap kebutuhan domestik dan peternakan di Sub DAS Lesti terjadi selama 4 bulan (bulan kering), yaitu bulan Agustus sampai Nopember. Hal ini disebabkan kebutuhan domestik dan non domestik tiap tahun meningkat, sedangkan ketersediaan air nya cenderung tetap.

2. Defisit air di sub DAS Lesti pada tahun 2017 sebesar $2.141 .057 \mathrm{~m}^{3}$ dan tahun 2023 sebesar $3.881 .593 \mathrm{~m}^{3}$.

3. Untuk mengatasi defisit air tersebut dilakukan upaya konservasi dengan 2 (dua) metode, antara lain metode vegetasi dan mekanik. Metode vegetasi adalah: penanaman pohon gaharu. Metode mekanis antara lain: pemanen air hujan dengan media atap dan embung.

4. Luas lahan vegetasi yang dibutuhkan untuk menangani masalah defisit tersebut sampai tahun 2023 antara lain: pohon gaharu seluas $18,27 \mathrm{~km}^{2}$, bambu $15,53 \mathrm{~km}^{2}$ dan tanaman porang $51,75 \mathrm{~km}^{2}$. Penyebaran tanaman tersebut di 7 kecamatan yang mengalami lahan rusak.

5. Kebutuhan pemanen air hujan dengan media atap untuk keperluan domestik pada musim kemarau ( 5 bulan) sebanyak 2 bak penampung dengan kapasitas masing-masing $32 \mathrm{~m}^{3}$ dengan dimensi $(4 \times 4 \times 2) \mathrm{m}$.

6. Pemanen air hujan selain dengan atap yaitu dengan pembangunan embung. Kebutuhan embung untuk mengatasi defisit air terhadap kebutuhan domestik dan peternakan sampai dengan tahun 2023 sebanyak 5 embung. 5 embung tersebut dikerjakan dengan 2 tahap. Tahan pertama 3 embung dengan kapasitas masing-masing $800.000 \mathrm{~m}^{3}$ dengan biaya investasi Rp. 264.187.069.875,- dikerjakan pada tahun 2017 s/d 2018. Tahap ke dua 2 embung dengan kapasitas masing-masing $800.000 \mathrm{~m}^{3}$ dengan biaya investasi $\mathrm{Rp}$. 192.476.718.300,- dikerjakan pada tahun 2020 s/d 2021.

7. Dari aspek finansial pembangunan embung tahap pertama (3 embung) dengan suku bunga bank pinjaman $11 \%$ pertahun nilai IRR = $13,89 \%>11 \%$; BCR, i $(11 \%)=1,05>1$ dan NPV,i $(11 \%)=$ Rp. 40.390.322.590,-. Pembangunan embung tahap ke dua (2 embung) dengan suku bunga bank pinjaman $11 \%$ pertahun nilai IRR $=14,51 \%>11 \%$; $\mathrm{BCR}, \mathrm{i}$ $(11 \%)=1,08>1$ dan NPV,i $(11 \%)=\mathrm{Rp}$. 35.983.932.804,--. Maka pembangunan embung tersebut secara finansial layak untuk dilaksanakan.

\section{UCAPAN TERIMA KASIH}

Penulis mengucapkan terima kasih kepada Pembimbing yang telah membimbing dan Kementerian Pekerjaan Umum yang telah memberikan beasiswa kedinasan.

\section{DAFTAR PUSTAKA}

[1] Arsyad, S (1989), Konservasi Tanah Dan Air, IPB Press, Bogor.

[2] Asdak. C, (2010), Hidrologi Dan Pengelolaan Daerah Aliran Sungai, edisi kelima (revisi), Gadjah Mada University Press, Yogyakarta.

[3] Badan Penanggulangan Bencana Daerah (2014), Kekeringan di Kabupaten Malang, Kabupaten Malang.

[4] Balai Besar Wilayah Sungai Brantas (2013), Data dan Informasi, BBWS Brantas, Surabaya.

[5] Britis Columbia (2002), Soil Water Storage Capacity And Available Soil Moisture, British Columbia, Canada.

[6] Crow, Peter (2005), The Influece Of Soil And Species On Tree Root Depth, Everonmental And Human Science Division, Endinburgh.

[7] Haryoso, B (2010), Teknik Pemanen Air Hujan (Rain Water Harvesting) Sebagai Alternatif Upaya Penyelamatan Sumber Daya Air Di Wilayah DKI Jakarta, Jurnal Sains dan Teknologi Modifikasi Cuaca, Vol. 11, No.2, 2010, hal 29-39.

[8] Mock, F.J, (1973), Land Capability Appraisal Indonesia, edisi pertama, Food And Agricultural Organization, Bogor.

[9] Pemerintah Kabupaten Malang (2014), Kabupaten Malang Dalam Angka, Badan Pusat Statistik Kabupaten Malang, Kabupaten Malang.

[10]Pemerintah Kabupaten Malang (2009), Kabupaten Malang Dalam Angka, Badan Pusat Statistik Kabupaten Malang, Kabupaten Malang.

[11]Pusat Penelitian Dan Pengembangan Hutan (2012), Budidaya Jenis Pohon Penghasil Gaharu, Puslitbang Produktivitas Hutan, Departemen Kehutanan, Bogor

[12] Sidharno, W (2013), Kajian Ketersediaan Air Baku Untuk Pemenuhan Kebutuhan Air Bersih Kota Kupang Dengan Skenario Dampak Perubahan Iklim, Tesis Master., Institut Teknologi Sepuluh Nopember Surabaya, Surabaya.

[13] Soemarto. CD, (1999), Hidrologi Teknik, edisi kedua, Erlangga, Jakarta.

[14] Sosrodarsono, Suyono, dan Takeda, Kensaku (2003), Hidrologi Untuk Pengairan, edisi kesembilan, Pradya Paramita, Jakarta.

[15] Sosrodarsono, Suyono, dan Takeda, Kensaku (2003), Hidrologi Untuk Pengairan, edisi kesembilan, Pradya Paramita, Jakarta.

[16] Triatmojo, Bambang, (2014), Hidrologi Terapan, edisi keempat, Beta Offset, Yogyakarta 